\title{
DOES EVERYTHING EXIST TO END UP IN A BOOK? MALLARMÉ AND THE AFTERMATH
}

Keywords: books, writing, philosophy, Mallarmé

Le monde est fait pour aboutir à un beau livre 'Everything in the world exists to end up in a book' (Mallarmé, 1945, 872). Mallarmés sentence is quoted by defiant bibliophiles, inhabitants of ivory towers, proponents of aestheticism, and many more-sometimes in disagreement ("although I do not share Mallarmés ...”), and sometimes without any clear intent, just to show that one is literary.

Mallarmés own mythical book is of course still a matter of great interest. ${ }^{1}$ However, it is not necessarily connected with his famous statement. His indisputable modernity has now shed all traces of fin-de-siècle symbolism, of flowers and fans. His hard-edge act of writing in a new way, the new interface of subjectivity and objectivity, connected with an amazing rank of topics, makes him almost a contemporary. There are texts about "Passing Fashion: Mallarmé and the Future of Poetry in the Age of Mechanical Reproduction" (Wayland-Smith, 2002, 887-907), there is Jacques Rancière's Mallarmé: La politique de la sirène (arguing strongly that Mallarmé is not a hermetic author, only a difficult one, deeply embedded in his time), and there is Robert Greer Cohn's “Mallarmés Wake” (1995, 885-901), once again explaining his pivotal position in modern thought and literature. Quite recently Patrick McGuiness wrote the following about "Mallarmé and the Poetics of Explosion":

1 Great but limited interest. It is more something for those that like their Mallarmé to remain a mystery, or incomprehensible; cf. Scherer (1977). 
What Mallarmé makes of the dangerous, messy, hubristic and often contradictory relations between art and everyday life is something unique, as exemplified in his article on Tailhade where life's broken pieces are recycled and reconfigured into a powerfully suggestive defense of poetry. Indeed we might think of the relations between art and politics in Mallarmés "Tailhade" as an instance of Divagations' dynamic and ongoing life/art recycling project-recycling being the pragmatist's alchemy, and Mallarmé being more of a pragmatist than many of us have allowed. (McGuiness, 2009, 824)

However, let me start with a classic text on the "Cult of Books." In Otras inquisiciones, Jorge Luis Borges condensed the cult into a few pages in which Mallarmé is used to illustrate an unacceptable idea: ${ }^{2}$

In the Book VIII of the Odyssey we read that the gods weave misfortunes into the pattern of events to make a song for future generations to sing. Mallarmés statement that the world exists in order to be written in a book seems to repeat, some thirty centuries later, the same concept of an aesthetic justification for evils. (Borges, 1960, 116)

The gods might introduce calamities to provide for future epic outbursts, but an aesthetic justification of evil is not really widely embraced. There might be some apologies for bad behavior in artists, but what we usually see is an aesthetic suspension of morality, not a reversal of desiderata.

Modernity is, of course, about the Good, the True, and the Beautiful not necessarily being connected. The modern world is disenchanted. Some fight against disenchantment by creating a theodicy of Beauty. Borges does not develop the "justification of evil" any further, but goes on to cover most of the obvious pre-modern ground of book worship and book denigration. We encounter Plato's arguments against writing from Phaedrus and some exalted passages from monotheistic religions, followed by the case of Don Quixote, speculation about the Book of Nature in Bacon's Advancement of Learning, and the telling statement from Thomas Browne's Religio Medici about all things being artificial because Nature is God's artifice. The last authority cited is much less widely appreciated: it is Léon Bloy from

2 That is, for the author of this paper. 
L'Ame de Napoleon, claiming that we all are words or letters of the one magic book, unique and endless: the world. Borges has simplified Mallarmés dictum and finished his text with a comparatively less known expression of an idea familiar from the Kabala or from Swedenborg. Furthermore, this idea goes against Mallarmés idea, literally in the other direction, because in Bloy the Book is always already there, it is not a goal or achievement.

Mallarmés sentence makes sense even without such a historical background. In the universe of writing (an activity I am engaged in while composing this paper), the book is the point, the goal, the ultimate achievement. It is an image, an idea, a foundational story, a metaphor we live by: perhaps all the more potent because we sense that the codex, the analogous book with its clear presence, iterability, and sameness of copies is in danger because we are accepting the inevitability of change. The one Book as a possible achievement offers a measure of solace because even the most diligent readers cannot really make headway in the infinity of books. Although the allotted number of five thousands books (Miedema, 2009, 67) we are said to be able to read in a lifetime seems rather low, it is still too much to be easily ordered. The singular, personal Book is not just something for believers: all readers work on it.

In a more sober approach, it is an obvious fact that we use transmitters (i.e., media) as metaphors for cognitive matters in the broadest of senses. Ideas are imprinted on wax tablets (tabulae rasae), a movie is playing before our eyes in mortal peril, and our brain is like a computer: such figurative use was and still is commonplace.

These metaphors are widespread and so is the metaphor of the book. Again, we turn to the obvious, a classic example, Ernst Robert Curtius. In his European Literature and the Latin Middle Ages there is a chapter on the "Book as Symbol" illustrating the comprehensive statement:

The use of writing and the book in figurative language occurs in all periods of world literature, but with the characteristic differences which are determined by the course of the culture in general. (Curtius, 1983, 303) 
The course of culture in general shows rather pedestrian and pedantic figurative speech about books side by side with exalted varieties. As interesting as some of the examples from Curtius are (long lines of complicated multi-tiered metaphors starting, for instance, with using "plough" for "write"), they concern us only where they run into trouble; that is, where their figurative functioning is disturbed. For instance: "The Book of Nature" appears at first to be a Renaissance rejection of scriptural truth, a declaration of looking for secular experience and knowledge. If we look closer we see that it was "medieval mystico-philosophical speculation" that was later "frequently secularized" (Curtius, 1983, 321), not abandoned, and the metaphor functions like that up to the Enlightenment and beyond. It is essentially pre-modern and Mallarmés sentence is not.

Printing, the advent of typographical man, changed the nature of reading; ${ }^{3}$ it changed the connection between reading (the one essential "Book") and writing. The Book is an object of worship and interpretation. Lower-case books simply proliferate.

Attitudes, of course, straddle epochs. Most pictures encountered today are simply pictures; some remain icons. Even at a much more intricate level, Walter Benjamin, for example, serves as an authority for speculative continuity. Daniel Heller-Roazen gives his introduction to Agamben's collected essays (1999) the title “To Read What Was Never Written," from Benjamin's "Theses on the Philosophy of History":

Historical method is philological method, a method that has as its foundation the book of life. "To read what was never written," is what Hofmannsthal calls it. The reader referred to here is the true historian. (Benjamin, cited in Agamben, $1999,1)$

Reading "what was never written" is the exact opposite of the book as goal and justification: it is a quest for redemption.

3 The works behind this thesis, by McLuhan, Febvre, Martin, and Eisenstein, have provoked and continue to give rise to a number of counterarguments, but this is not the place to deal with them. 
The ambivalent new mood in the figurative use of the book and writing is perhaps best expressed in Jean-Luc Nancy's slim volume On the Commerce of Thinking (2009), written originally as an occasional piece to celebrate a bookstore. It exemplifies the predicament it comments on: our situation in the midst of endless ("analogous") books being increasingly confronted with digitally transmitted texts, some of them clearly books as well. Every aspect of books and bookstores is connected with the title: with the commerce of thinking.

For, in the end, the Idea of the book will always, from its very first conception, have been the Idea of its reading and, through that reading, the Idea of another book, of another writing that continues on from the first. Not necessarily the writing of another book, but at the very least the writing of another tracing or thinking, another curve, volute, or meander of representation, of meditation, imitation, or creation. The Idea of the book is the Idea that there is no end to this very Idea, and that it contains nothing less than its own proliferation, its multiplication, its dispersion, and always, at some moment and in some respect or another, there is the silent or eloquent advice from the book that it is an invitation to throw it away, to abandon it. In fact reading does not lead to more reading, but to everything else, to what is sometimes called action and sometimes experience, where we rub against the illegible real. (Nancy, 2009, 41-42)

There is something outside the text, very much so. The digital innovations suddenly reinforce the role of the return of the Real. Nancy writes about the screen, neither a medium nor a message, "but a subtle and ductile electricity propagating an uninterrupted excitement in a text that perhaps in the end says only that, that it is excited in favor of its propagation" (2009, 51). Also:

Indefinite expansion and in every sense, in all directions of the internal invisible proliferation of virtual pages that the screen swallows and bounces back, digests and regurgitates at will, and where do they go, lying low, compressed, vaporized, reduced to a gaseous state a luminous state in order to spring back out of storage shining and ready for printing again for Gutenberg returns as a rapid laser jet burst of ink printer blocks of wood transmuted into ink cartridges. (Nancy, 2009, 55) 
New experiences suddenly transform the long-reigning facile deconstruction of what happens after the last sentence of a book. The book is used by Jacques Rancière in a programmatic sense in The Flesh of Words. He writes about the book projected toward a reality that is not the one it speaks of, but the one in which it must become a deed, a power of life. The book is now directly included in the "performative" functions of language, in the naming, calling, and commanding. Mallarmés poetry, not mimetic, not descriptive, condemning resemblance, becomes part of the relationship between literature, philosophy, and politics because of this and not despite it.

It would be foolhardy to attempt a comprehensive overview of recent metaphors of books and writing. A very simple conclusion from my examples is as follows: in a rather influential type of theory, books are neither seen as an ultimate achievement nor as a paradigm for the way everything is (that is, the world as a more or less readable text). They are treated as deeply enmeshed in everything that is going on, as deploying themselves, acting upon us.

Older metaphors are still used and effective, but there seems to be a clear and present shift. Maurice Merleau-Ponty picked up the phrase "the prose of the world" from Hegel and liberated it from its context of twilight, of disenchantment, but did not do very much more then use an elegant expression. The current use of the book as metaphor is connected with a specific definition of philosophy; it is philosophy as the production of concepts, but a production claiming to be rigorous, connected to method: albeit not to science. ${ }^{4}$ Furthermore, it is a production of concepts made to be influential. The materiality of the book and the "commerce" of thinking are central to such an enterprise.

A final remark: the figurative use of the book and writing today is less connected than in former constellations. The immense influence of Jacques Derrida (cf. Nunez, 2010) still monopolizes the philosophical concept of "writing."

4 Science-related philosophy in the French manner is of course a startling new development in the work of "speculative realism" in Meillassoux, Brassier, and Malabou.

5 However, this is only a small part of the research. The "materialities of communication" are a matter of interest in a number of disciplines. As an early example, compare Gumbrecht and Pfeiffer (1994). 
"The book" allows a different approach. Ambiguities can be artfully exploited. The figurative use of the "book" and new concepts of the book are sometimes difficult to distinguish, even in the broadest figures: "The Book of the World," "The Book of Nature." At the first level, it seems simple: the world is like a book; we can read it, and it makes sense. However, seen the other way; a book is like the world, it contains the world, it justifies the world: the world leads us to "The Book." Instead of such permutations, we are looking for the worldliness of books, their existing role, connected or not with what they are "about."

\section{REFERENCES}

Agamben, Giorgio. Potentialities. Stanford: Stanford UP, 1999.

Borges, Jorge Luis. Otras inquisiciones. Buenos Aires: Emecé Editores, 1960.

Brassier, Ray. Nihil Unbound. London: Palgrave Macmillan, 2007.

Cixous, Hélène. “The Book as One of Its Own Characters." New Literary History 33.3 (2002): 404-34.

Curtius, Ernst Robert. European Literature and the Latin Middle Ages. Princeton, NJ: Princeton UP, 1983.

Eisenstein, Elizabeth L. The Printing Revolution in Early Modern Europe. Cambridge: Cambridge UP, 2005.

Febvre, Lucien, and Henri-Jean Martin. The Coming of the Book. London: Verso, 1997.

Geer Cohen, Robert. “Mallarmés Wake.” New Literary History 26.4 (1995): 885-901.

Gumbrecht, Hans Ulrich, and Karl Ludwig Pfeiffer. Materialities of Communication, Stanford: Stanford UP, 1994.

Malabou, Catherine. What Should We Do with Our Brain? New York: Fordham UP, 2008.

McGuinness, Patrick. "Mallarmé and the Poetics of Explosion." MLN 124.4 (2009): 797-824.

Meillassoux, Quentin. After Finitude. London: Continuum, 2009. 
Miedema, John. Slow Reading. Duluth: Litwin Books, 2009.

Nancy, Jean-Luc. On the Commerce of Thinking. New York: Fordham U P, 2009.

Nunez, Laurent. “Derrida en héritage.” Le Magazine Littéraire 498 (June 2010): 56-57.

Rancière, Jacques. Mallarmé. Paris: Hachette, 1996.

Rancière, Jacques. The Flesh of Words. Stanford: Stanford UP, 2004.

Sartre, Jean-Paul. Mallarmé. Paris: Gallimard, 1986.

Scherer, Jacques. Le "Livre" de Mallarmé. Paris: Gallimard, 1977.

Wayland-Smith, Ellen. "Passing Fashion: Mallarmé and the Future of Poetry in the Age of Mechanical Reproduction.” MLN 117.4 (2002): 887-907. 


\section{ALI VSE OBSTAJA ZATO, DA BI PRISTALO V KNJIGI? MALLARMÉ IN NJEGOVA DEDIŠČINA}

Ključne besede: knjige, pisanje, filozofija, Mallarmé

\section{Povzetek}

Prispevek je pregled sodobnih branj in izpeljav Mallarméjeve znamenite izjave; obravnava vrsto avtorjev, od Borgesa in E. R. Curtiusa do sodobnih francoskih filozofov, in se pri tem ukvarja tudi z usodo "analogne« knjige $\mathrm{v}$ digitalni dobi. 


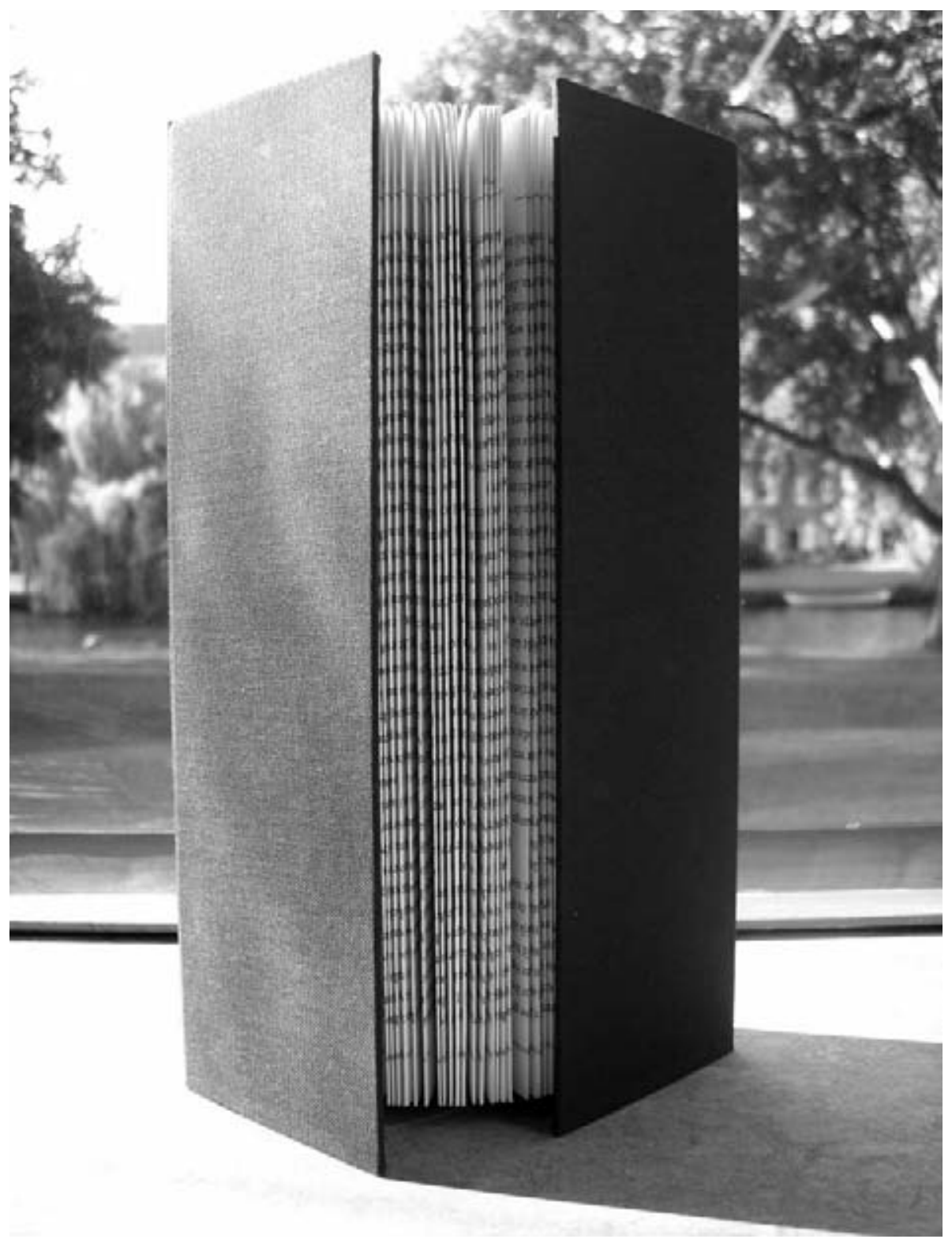

Fleur Thio: A slow book (2009)

"Rather than wanting to be in a hurry while reading I usually long for the possibility to actually escape the hectic outside world and really take my time to discover a book. The 'slow book' could be the answer to that longing. Because every page has been folded the only option is to sit down and concentrate on both the motion of folding out each sheet and reading the text." 